\title{
A review on synthetic account of 1,2,4-oxadiazoles as anti-infective agents
}

\author{
Tejas M. Dhameliya ${ }^{1} \mathbb{D} \cdot$ Shrddhaba J. Chudasma ${ }^{1} \cdot$ Tanvi M. Patel $^{1} \cdot$ Bhavarth P. Dave $^{1}$
}

Received: 20 October 2021 / Accepted: 24 December 2021 / Published online: 5 January 2022

(c) The Author(s), under exclusive licence to Springer Nature Switzerland AG 2022

\begin{abstract}
Most of the currently marketed drugs consist of heterocyclic scaffolds containing nitrogen and or oxygen as heteroatoms in their structures. Several research groups have synthesized diversely substituted 1,2,4-oxadiazoles as anti-infective agents having anti-bacterial, anti-viral, anti-leishmanial, etc. activities. For the first time, the present review article will provide the coverage of synthetic account of 1,2,4-oxadiazoles as anti-infective agents along with their potential for SAR, activity potential, promising target for mode of action. The efforts have been made to provide the chemical intuitions to the reader to design new chemical entity with potential of anti-infective activity. This review will mark the impact as the valuable, comprehensive and pioneered work along with the library of synthetic strategies for the organic and medicinal chemists for further refinement of 1,2,4-oxadiazole as anti-infective agents.
\end{abstract}

\section{Graphical abstract}

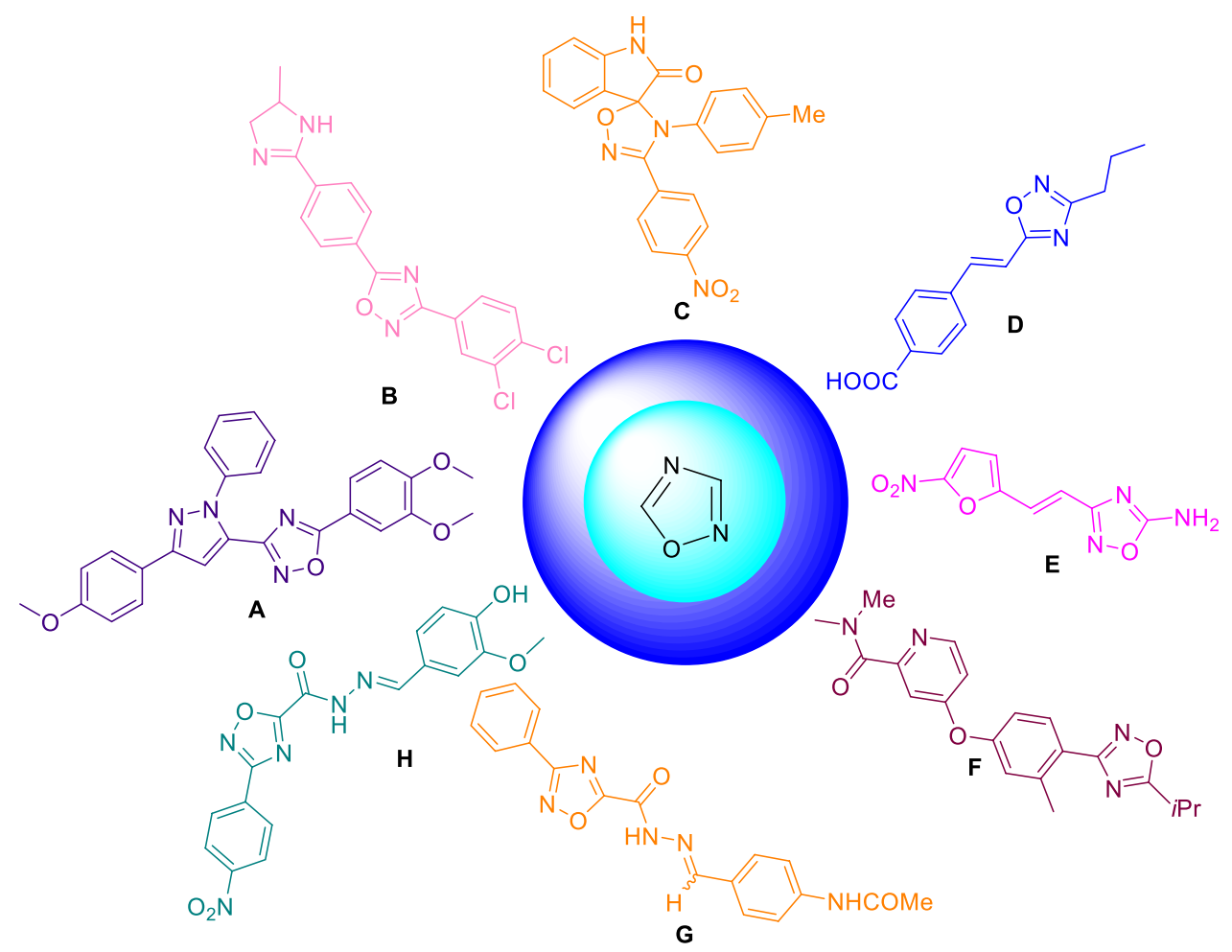

Keywords 1,2,4-Oxadiazoles $\cdot$ Anti-infective $\cdot$ Anti-bacterial $\cdot$ Anti-malarial $\cdot$ Synthesis

Extended author information available on the last page of the article 


$\begin{array}{ll}\text { Abbreviations } \\ \text { CDI } & \text { Carbonyl diimidazole } \\ \text { DIPEA } & \text { Di-isopropyl ethyl amine } \\ \text { DMAP } & \text { Dimethylaminopyridine } \\ \text { DMF } & \text { Dimethylformamide } \\ \text { DMSO } & \text { Dimethylsulfoxide } \\ \text { EDC·HCl } & \text { (3-Dimethylaminopropyl)carbodiimide } \\ & \text { hydrochloride } \\ \text { EtOH } & \text { Ethanol } \\ \text { SARS CoV-2 } & \text { Severe acute respiratory syndrome } \\ & \text { coronavirus-2 } \\ \text { TBAF } & \text { Tetra- } n \text {-Butyl ammonium fluoride } \\ \text { TBDMS } & \text { tert-Butyl dimethylsilyl } \\ \text { TFAA } & \text { Trifluoroacetic anhydride } \\ \text { THF } & \text { Tetrahydrofuran }\end{array}$

\section{Introduction}

Most of the parts of the world have been affected from deadly infectious disease including tuberculosis (Mycobacterium tuberculosis, Mtb) [1, 2], malaria (Plasmodium falciparum) [3], Chagas disease or American trypanosomiasis (Trypanosoma cruzi) [4], nosocomial infections (Staphylococcus aureus or methicillin-resistant S. aureus, MRSA) [5] and also the recent severe acute respiratory syndrome coronavirus-2 (SARS CoV-2, caused by Coronavirus) [6-8]. The scarcity of curative action of antibiotics and anti-infective agents and complex genomic structure of microorganism has led to resistance among them leading to ineffectiveness of the currently used treatment regimen [9]. The resistance to antibiotics has become a threat to the world in the absence of effective anti-infective therapeutics with the demand of new hybrid drugs acting against resistant microorganism [10]. These all facts have necessitated the urge of new chemical entities to act against these microorganisms.

\section{4-Oxadiazoles as important heterocyclic scaffolds}

The synthesis of nitrogen- and oxygen-containing scaffolds has gained momentum [11-15] due to their versatility in the arsenal of drug discovery [16-18]. Oxadiazoles, being five-membered heterocyclic scaffold with an oxygen and two nitrogen atoms constitute four regioisomeric structures such as 1,2,3-oxadiazole, 1,2,5-oxadiazole, 1,2,4-oxadiazole and 1,3,4-oxadiazole. Oxadiazoles possess hydrogen bond acceptor properties [19] owing to electronegativities of nitrogen and oxygen, wherein nitrogen has been stronger hydrogen bond acceptor than oxygen [20]. Additionally, oxadiazoles have been recognized as the bioisosteres of (hydroxamic) esters, carboxamides and carbamates leading to metabolic stability to parent scaffolds [21]. Among these isomeric oxadiazoles, 1,2,4-oxadiazoles have found many applications in pharmaceutical industry for drug discovery, scintillating materials and dyestuff industry [22]. Oxadiazoles are also synthesized from green chemistry approach which microwave-assisted synthesis which is low cost and also they are not producing any toxic material during the preparation of oxadiazoles [23]. Following the search through Scopus using the keywords "1,2,4-oxadiazoles," research on 1,2,4-oxadiazoles has been expanding exponentially year by year (Fig. 1) [24].

Nowadays, there are a few commercially available drugs containing 1,2,4-oxadiazole nucleus [25] such as pleconaril (anti-infective) [26], oxolamine (anti-inflammatory) [27], prenoxdiazine (cough suppressant), butalamine (vasodilator) [28], ataluren (use in Duchenne muscular dystrophy) [29] and proxazole (used for anti-tussive and anti-plasmodic) [30] (Fig. 2). Additionally, a few marine natural products such as phidianidine A and B possess 1,2,4-oxadiazole as key pharmacophoric features [31]. Apart from this, 1,2,4-oxadiazoles have been recognized as the important scaffold of biological importance [32] along with anti-cancer [33-37], anti-inflammatory [38-40], analgesic [41], anti-Alzheimer [42], monoamine oxidase-B (MAO-B) inhibitor [43] and anti-oxidant activities [44].

The 1,2,4-oxadiazoles (A-H) have been recognized as the scaffold of biological importance for anti-parasitic activity (Fig. 3) [45-52]. These 1,2,4-oxadiazoles have been reported as anti-fungal [45], anti-microbial [53], antiinflammatory, anti-trypanosomal [51, 54], anti-malarial [52], anti-mycobacterial [48], and anti-viral [55]. In 2018, Lima and co-workers have reported the importance of 1,2,4-oxadiazoles as anti-parasitic agents along with other isomeric 1,3,4-oxadiazoles [56]. Recently, de Souza et al. have reported the synthetic applications of nitriles for the synthesis of 1,2,4-oxadiazoles along with 1,2,5-oxadiazoles, 1,3-oxazoles and 2-oxazolines reported during 2014-2021 [57]. To the best of our knowledge, there is no specific synthetic account on synthetic strategies for 1,2,4-oxadiazoles as anti-infective agents till date. In the present work, we made the efforts to summarize the reported synthetic strategies of 1,2,4-oxadiazoles as anti-parasitic agents with the emphasis on identified hits, and their key SARs, etc.

\section{Synthetic account of 1,2,4-oxadizoles with anti-infective activity}

The oxadiazole scaffolds having anti-infective activity were prepared from different synthetic strategies involving the use of amidoxime with carbonyl compounds such as carboxylic acids (Route A, Fig. 4) [45, 48], aldehydes (Route B) [53], 2-chloro-2-oxoacetate (Route C) [51, 55, 
2500

2000

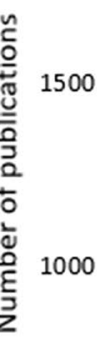

500

0

200020012002200320042005200620072008200920102011201220132014201520162017201820192020

Publication Year

Fig. 1 Exponential growth of on-going research on 1,2,4-oxadiazoles retrieved by Scopus on Sept 27, 2021 using the keywords "1,2,4-oxadiazoles." [24]

Fig. 2 Chemical structures of commercial drugs and natural products based on a 1,2,4-oxadiazole scaffold<smiles>CCCCOc1c(C)cc(-c2noc(C(F)(F)F)n2)cc1C</smiles><smiles>CCN(CC)CCc1nc(-c2ccccc2)no1</smiles>

Oxolamine<smiles>O=C(O)c1cccc(-c2noc(-c3ccccc3F)n2)c1</smiles>

Ataluren<smiles>CCCCN(CCCC)CCNc1nc(-c2ccccc2)no1</smiles><smiles>c1ccc(C(Cc2noc(CCN3CCCCC3)n2)c2ccccc2)cc1</smiles>

Prenoxadiazine<smiles>[R1]c1ccc(/C(=C/N)Cc2nc(NCCCNC(=N)N)no2)cc1</smiles>

58], and ester (Route D) [46]. Along with these, other routes such as intramolecular cyclization of ester clubbed with amidoxime (Route E) have been reported by Raval et al. [59] with high atom economy. Another excellent approach involving use of aminonitrone, hydroxylamine and isocyanide at $\mathrm{rt}$ to yield 1,2,4-oxadiazole (Route F) has been also attempted for the synthesis of anti-infective 1,2,4-oxadiazoles [60]. The present review article has been organized with the focus on the synthetic strategies using all these routes $\mathrm{A}-\mathrm{F}$. 
Fig. 3 Scaffolds of the 1,2,4-oxadiazoles with different anti-infective activities [45-52]
Fig. 4 Synthetic strategies for accessing anti-infective 1,2,4-oxadiazole scaffold

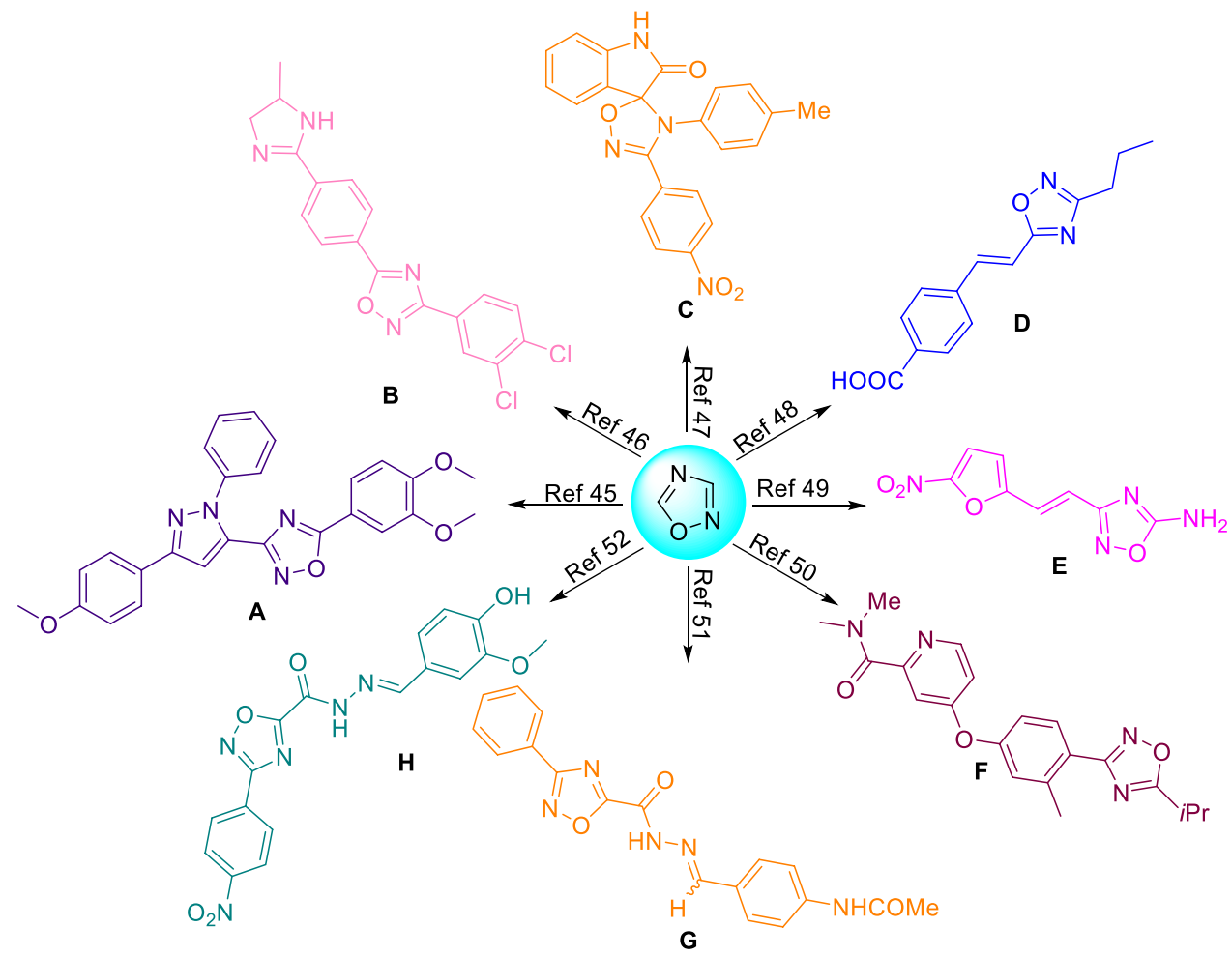

\section{Reported synthesis of 1,2,4-oxadizoles as anti-infective agents}

Bhadraiah et al. [45] reported 1,2,4-oxadiazoles as antiinfective agents having anti-bacterial, anti-fungal, antiinflammatory activity. Chloramine-T mediated synthesis of $N$-phenyl pyrazolines was achieved by cyclocondensation
Route C

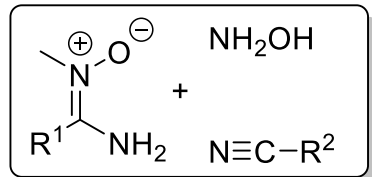

Route F<smiles>C=CC=C</smiles><smiles>C=CC</smiles><smiles>CC1CC1</smiles>

$\mathrm{N}-\mathrm{O}$

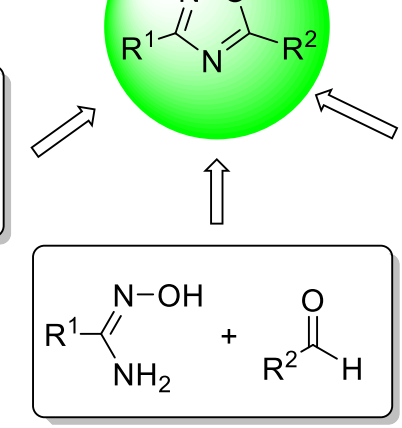
$\checkmark$ $\mathrm{R}^{1}-_{\mathrm{NH}_{2}}^{\mathrm{N}-\mathrm{OH}}+\mathrm{R}^{2} \stackrel{\mathrm{O}}{\mathrm{Cl}}$

Route B

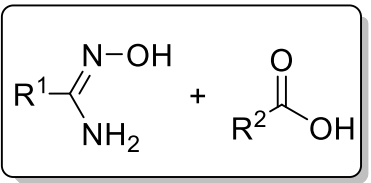

Route A

of $N$-phenyl hydrazine (1) with acrylonitrile (2) in ethanol at reflux for $3 \mathrm{~h}$. Next, 4,5-dihydro-1,3-diphenyl$1 H$-pyrazole-5-carbonitrile (3) was treated with hydroxyl amine hydrochloride (4) in aqueous ethanol to afford the synthesis of amidoxime (5) at reflux for 5-6 h. Next, 5 was treated with carboxylic acids (6) using 1-ethyl3-(3-dimethylaminopropyl)carbodiimide hydrochloride 
$(\mathrm{EDC} \cdot \mathrm{HCl})$ in dichloromethane at $0-30{ }^{\circ} \mathrm{C}$ for $6 \mathrm{~h}$ followed by stirring at $110^{\circ} \mathrm{C}$ to synthesize $1,2,4$-oxadiazoles (7, Scheme 1). Further, 7 was reacted with bromine to undergo oxidation to form aromatic pyrazoline derivative of 1,2,4-oxadiazole (8). Compounds 7 with substitutions $\left(\mathrm{R}^{1}=4-\mathrm{OMe}-\mathrm{C}_{6} \mathrm{H}_{4} ; \mathrm{R}^{2}=3,4-(\mathrm{OMe})_{2}-\mathrm{C}_{6} \mathrm{H}_{3}\right)$ were found with the best anti-microbial activity (MIC of $10 \mu \mathrm{g} /$ $\mathrm{mL}$ ) and $\mathbf{7}$ having $\mathrm{R}^{1} / \mathrm{R}^{2}$ as 4 -chlorophenyl as potent antiinflammatory activity.

Srivastava et al. [53] reported the synthesis of 3-aryl5-propyl-1,2,4-oxadiazole (12) by manganese dioxide mediated oxidation of 3-aryl-5-propyl-4,5-dihydro-1,2,4,oxadiazole (11), obtained from cyclocondensation of arylamidoxamines (9) with $n$-butanal (10, Scheme 2). A small quantity of acidic ion-exchange resin (amberlite IRP-64) as catalyst has yielded $\mathbf{1 1}$ in 3 days instead of 5-8 days. Secondly, addition of sodium hypochlorite in a mixture of tetrahydrofuran and water yielded $\mathbf{1 2}\left(\mathrm{R}^{1}=\mathrm{H}\right)$ from $\mathbf{1 1}$ $\left(\mathrm{R}^{1}=\mathrm{H}\right)$ in $89 \%$ yields. Upon the evaluation of compounds $\mathbf{1 1}$ against microorganisms, compounds $\mathbf{1 1}$ with 3-methyl and 4-methoxy substitutions were found more effective against $S$. aureus, $M$. smegmatis and $C$. albicans. Further, they have performed the evaluation of anti-inflammatory activity of compounds 12, however, although no compounds were found potent than aspirin during in vivo assay.

Filho et al. [51] reported the synthesis of 3-(4-susbstituted-aryl)-1,2,4-oxadiazolyl- $N$-acylhydrozone (18) as antitrypanosomal agents (Scheme 3 ). The cyclocondensation of aryl amidoximes (9) and methyl 2-chloro-2-oxoacetate (13) under reflux in tetrahydrofuran yielded 1,2,4-oxadiazole (14) which was further treated with hydrazine hydrate (15) to get the $E$ and $Z$ mixture of $N$-acylhydrazides (16) at $0{ }^{\circ} \mathrm{C}$ for $60 \mathrm{~min}$. Finally, its acid-catalyzed addition-elimination reaction with 4-substituted benzaldehydes (17) at reflux in ethanol yielded (18) in 83-98\% yields. Further, they speculated the formation of $E$ isomer as major and thermodynamically stable product considering their conformational and configurational energies rather than $Z$ isomer. Further, they studied the probable mode of action of the synthesized compounds against Trypanosoma cruzi cysteine protease cruzain using molecular docking (PDB ID: 1U9Q) followed by evaluation of cytotoxicity and anti-trypanosomal activity. Compounds (18) with $\mathrm{R}^{1}=\mathrm{H}$ and $\mathrm{R}^{2}=\mathrm{NHCOMe}$ were found with the satisfactory $\mathrm{IC}_{50}$ of $3.6 \mu \mathrm{M}$. The evaluation of in vivo toxicity in mice revealed this compound as non-toxic to mice at the concentration of $100 \mathrm{mg} / \mathrm{kg}$.
Scheme 1 Synthesis of 1,2,4-oxadiazoles (7/8) having anti-bacterial and antifungal activity. Conditions: (i) Chloramine-T, EtOH, reflux, $3 \mathrm{~h}$; (ii) $\mathrm{Na}_{2} \mathrm{CO}_{3}$, aq. EtOH, reflux, 5-6 h; (iii) $\mathrm{EDC} \cdot \mathrm{HCl}$, DCM, 0-30 ${ }^{\circ} \mathrm{C}, 1-2 \mathrm{~h}$, then rt for $6 \mathrm{~h}$ followed by $110^{\circ} \mathrm{C}, 6 \mathrm{~h}$; (iv) $\mathrm{Br}_{2}, \mathrm{DCM}$, reflux, $1 \mathrm{~h}$
Scheme 2 Synthetic strategy for 3-aryl-5-propyl$1,2,4$,oxadiazoles (12) reported by Srivastava and co-workers. Conditions: (i) $\mathrm{EtOH}, \mathrm{H}_{2} \mathrm{O}$, rt, 5-8 days; (ii) $\mathrm{MnO}_{2}$, (3.8 equiv), DCM, rt, $2 \mathrm{~h}$

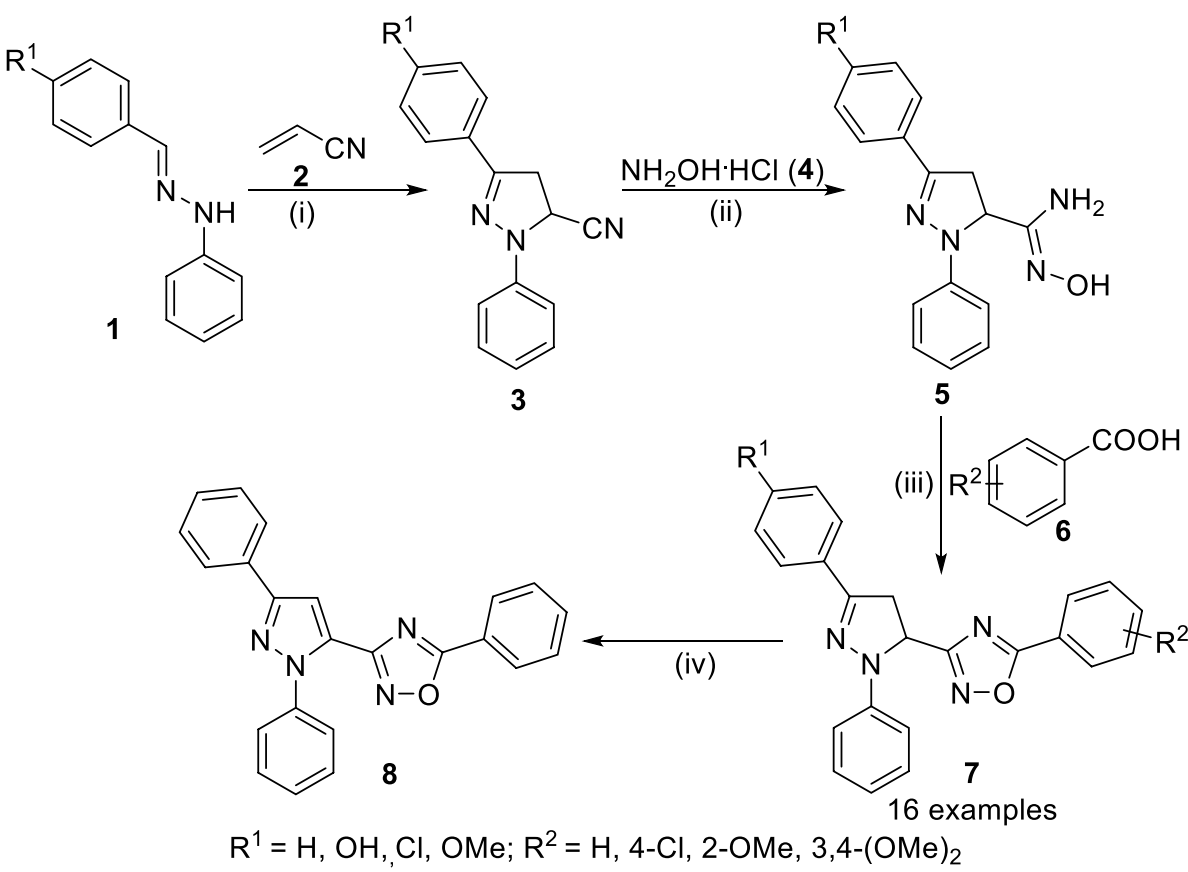

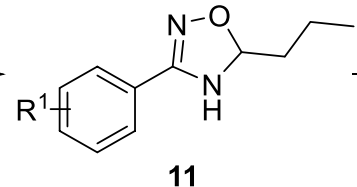

11

$\mathrm{R}^{1}=\mathrm{H}, 2-\mathrm{Me}, 3-\mathrm{Me}, 4-\mathrm{Me}, 4-\mathrm{Cl}, 4-\mathrm{OMe}$<smiles>C#C[R1]1cccc(-c2noc(CCC)n2)c1</smiles>

(74-95\%) 
Scheme 3 Synthesis of 3-(4-susbstituted-aryl)-1,2,4oxadiazolyl- $N$-acylhydrozone (18) acting against $T$. cruzi . Conditions: (i) THF, reflux, $4.5 \mathrm{~h}$; (ii) $\mathrm{EtOH}, 0^{\circ} \mathrm{C}, 60 \mathrm{~min}$ (iii) $\mathrm{H}_{2} \mathrm{SO}_{4}, \mathrm{EtOH}, \mathrm{rt}, 10 \mathrm{~min}$

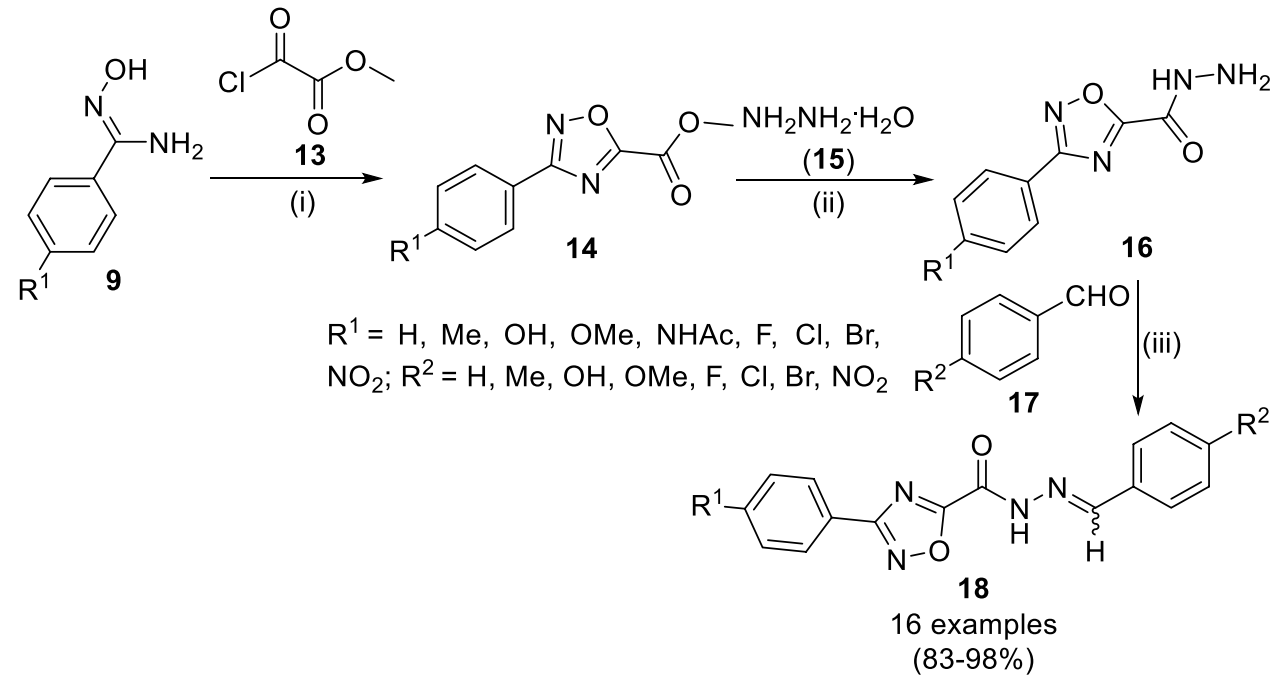

Filho et al. reported the trypanosomicidal [54] and antimalarial [52] activity of 1,2,4-oxadiazole conjugated with $N$-acylhydrazone (19 and 22, Scheme 4). In 2012, they reported the treatment of 4-substituted aryl amidoximes (9) with methyl 2-chloro-2-oxoacetate (13) at reflux for 4-4.5 h to synthesize 1,2,4-oxadiazoles (14) in good yields. This was followed by their sequential reactions with hydrazine (20) and aldehydes (21) to yield 3,5-disubstitute 1,2,4-oxadiazoles (22) in $80-99 \%$ yields. Compounds 22 with $\mathrm{R}^{2}$ as methylene 3,4-methylenedioxybenzene substitutions having $\mathrm{R}^{1}$ as chloro and fluoro substitutions were found with potent $\mathrm{IC}_{50}$ of $9.5 \pm 2.8$ and $3.5 \pm 1.8 \mu \mathrm{M}$, respectively, against $T$. cruzi [54]. The similar synthetic methodology was adopted in 2016 by them for the synthesis of 1,2,4-oxadiazoles (22) as anti-malarial compounds by using styryl and ferrocene carboxaldehydes (21) [52]. Herein, the $\mathrm{H}_{2} \mathrm{SO}_{4}$ catalysts did not afford the product (22) with ferrocene carboxaldehyde, so the alternative Lewis acid catalysts, cerium chloride $\left(\mathrm{CeCl}_{3} \cdot 7 \mathrm{H}_{2} \mathrm{O}\right)$ was tried to yield thermodynamically stable
$E$-isomers (22). These anti-malarial compounds, synthesized in the laboratory of design and synthesis applied to medicinal chemistry-SintMed ${ }^{\circledR}$ inhibited the formation of $\beta$-hematin, which has been recognized as the mechanism of quinoline-based anti-malarial $\beta$-hematin inhibitors. Despite of diminished parasitemia, the most active compound $\mathbf{2 2}$ $\left(\mathrm{R}^{1}=\mathrm{NO}_{2} ; \mathrm{R}^{2}=4-\mathrm{OH}-3-\mathrm{OMe}-\mathrm{C}_{6} \mathrm{H}_{3}\right.$, with $69 \%$ inhibition of chloroquine-resistant $P$. falciparum $\mathrm{W} 2$ strain) did not show any improvement in survival of Plasmodium bergheiinfected mice during the in vivo studies as compared to chloroquine, marketed anti-malarial drug.

Several nitrogen- and oxygen-containing scaffolds have been found of much interest due to their potential as antimycobacterial agents $[15,17,18,61-63]$. In this regard, Upare and coworkers reported the anti-tubercular activity of (E)-3-alkyl-5-styryl 1,2,4-oxadiazoles [48]. The treatment of benzaldehyde (23) with malonic acid (24) in the presence of catalytic amount of piperidine at $110{ }^{\circ} \mathrm{C}$ yielded cinnamic acid (25), which was reacted with amidoxime (26,
Scheme 4 Synthetic strategy of 3,5-disubstituted oxadiazoles (16 and 22) as trypanosomicidal and anti-malarial agents. Conditions: (i) $\mathrm{Na}_{2} \mathrm{CO}_{3}, \mathrm{H}_{2} \mathrm{O}$ / $\mathrm{MeOH}, 4 \mathrm{~h}$, reflux; (ii) dry THF, reflux, 4-4.5 h; (iii) $\mathrm{EtOH}, 0{ }^{\circ} \mathrm{C}, 2 \mathrm{~h}$; (iv) $\mathrm{H}_{2} \mathrm{SO}_{4}$ or $\mathrm{CeCl}_{3} \cdot 7 \mathrm{H}_{2} \mathrm{O}(10 \mathrm{~mol} \%)$, EtOH, $40{ }^{\circ} \mathrm{C}, 10-30 \mathrm{~min}$

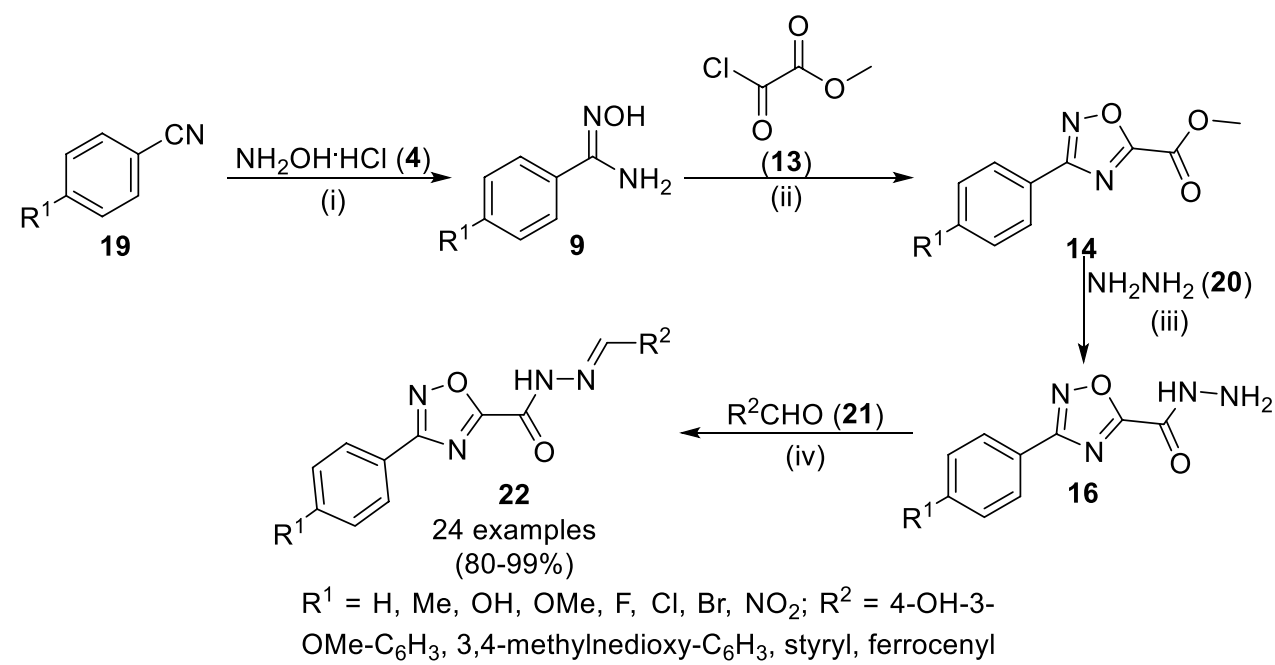


Scheme 5) using carbonyl diimidazoles (CDI) in toluene to obtain 3,5-disubstituted 1,2,4-oxadiazole derivatives (27). Following the SAR studies of 1,2,4-oxadiazoles with different functional groups on the phenyl ring of cinnamic acid, electron-withdrawing groups and halogens were found with good anti-tubercular activity in comparison with electron-donating and bulky substituents. Whereas the chain length and bulkiness at $3^{\text {rd }}$ position of 1,2,4-oxadiazoles increased anti-mycobacterial potential. The compound $\mathbf{2 7}$ $\left(\mathrm{R}^{1}=\mathrm{COOH} ; n=2\right)$ was reported with promising anti-TB activity against $M$. tuberculosis $\mathrm{H}_{37} \mathrm{Ra}$ having higher antiTB activity with $\mathrm{IC}_{50}$ of 0.63 and MIC of $8.45 \mu \mathrm{g} / \mathrm{mL}$ after 12 days of incubation. Further, the molecular modeling studies against InhA revealed their binding mode in the active site of enoyl-ACP reductase InhA.

Jung and coworkers have designed the 3-aryl-1,2,4oxadiazoles (36) [55] having activity potential against human rhinovirus from their previously identified 2,6-disubstituted benzo[ $[d]$ thiophene derivative [50]. The conversion of hydroxy benzoic acid $\mathbf{2 8}$ into acid chloride and benzamide intermediate (29) was followed cyanation of 29 using trifluoracetic anhydride (TFAA) in pyridine to yield hydroxy benzonitriles (30, Scheme 6). The synthetic target picolinamide clubbed 3-phenyl-1,2,4-oxadiazoles (33) was obtained by treatment of $\mathbf{3 0}$ with hydroxyl amine hydrate (31) to get amidoxime (32) followed by cyclization using acyl chloride (33) and $O$-arylation using 4-chloro$\mathrm{N}$-methylpicolinamide (35). The biological investigation of compounds $\mathbf{3 6}$ against rat and human liver revealed compound $36\left(\mathrm{R}^{1}=3-\mathrm{Me}, \mathrm{R}^{2}=i \operatorname{Pr}, \mathrm{R}^{3}=\mathrm{Me}\right)$ with highest stability under hepatic microsomal conditions (with 60 and $41 \%$ of compound being unmetabolized, respectively). Further, it showed the significant efficacy against human rhinovirus (hRV-A71, hRV-B14 and hRV-A21) with better inhibitory concentration $\left(\mathrm{EC}_{50}\right.$ of $3.7,66.0$ and $22.0 \mathrm{nM}$, respectively). However, in vivo pharmacokinetic analysis

Scheme 5 Synthesis strategy of (E)-3 alkyl-5-styryl-1,2,4oxadiazoles (27) as anti-tubercular agents adopted by Upare et al. Conditions: (i) piperidine, pyridine, $110^{\circ} \mathrm{C}, 10-12 \mathrm{~h}$; (ii) $\mathrm{CDI}, \mathrm{PhMe}, \mathrm{rt}, 3-4 \mathrm{~h}$ followed by $100-110^{\circ} \mathrm{C}, 5-6 \mathrm{~h}$<smiles>[R1]C[R](C)(C)COC(=O)/C=C/c1ccc[R11](CC)c1</smiles>

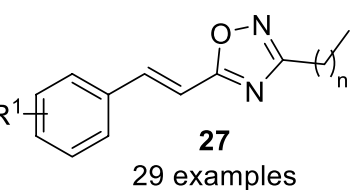
29 examples $(40-60 \%)$ $\mathrm{n}=2,8$ $\mathrm{R}^{1}=\mathrm{H}, 3-\mathrm{Me}, 4-\mathrm{Me}, 4-\mathrm{OH}, 2,5-(\mathrm{OH})_{2}$, 4-OMe, 2,4-(OMe $)_{2}, 2,5-(\mathrm{OMe})_{2}, 3,4-(\mathrm{OMe})_{2}, 4-\mathrm{OH}-$ 3-OMe, 5-OH-2-OMe, 4-SMe, 4-F, 4-Cl, 2-Cl, 3-Br, 4-Br, 2,4-(Cl $)_{2}, 3,4-(\mathrm{Cl})_{2}$, 2-Br-4-F, 3-F2-OMe, 3-F-4-OMe, 3- $\mathrm{CF}_{3}, 4-\mathrm{COOH}, 4-\mathrm{SOMe}, 4-\mathrm{SO}_{2} \mathrm{Me}, 4-\mathrm{CN}, 2-\mathrm{NO}_{2}$<smiles>[R]c1ccc(O)cc1C(=O)O</smiles>

28<smiles>[R1]C1CCCCC1C(N)=O</smiles>

(iii)<smiles>[R]c1cccc(O)c1C#N</smiles>

30<smiles>[R12]c1ccc(/C(N)=N/O)cc1</smiles><smiles>[R]c1nc(-c2cccc(Oc3ccnc(C(=O)N([R])C)c3)c2)no1</smiles>

20 examples

$(8-48 \%)$

$\mathrm{R}^{1}=\mathrm{H}, 2-\mathrm{Me}$, 3-Me, 2,6-(Me $)_{2} ; \mathrm{R}^{2}=\mathrm{Me}, \mathrm{Et}, n \mathrm{Pr}, i \mathrm{Pr}, i \mathrm{Bu}, \mathrm{CH}_{2} \mathrm{OMe}, \mathrm{CF}_{3} ; \mathrm{R}^{3}=\mathrm{H}, \mathrm{Me}$

Scheme 6 Strategy for the multi-step synthesis of phenyl oxadiazole compound (36) acting against human rhinovirus. Conditions: (i) $\mathrm{SOCl}_{2}, \mathrm{DMF}, 70{ }^{\circ} \mathrm{C}$; (ii) $\mathrm{NH}_{3}, \mathrm{H}_{2} \mathrm{O}$, THF, $0-25^{\circ} \mathrm{C}, 5 \mathrm{~h}$; (iii) TFAA, pyridine, $16 \mathrm{~h}$; (iv) EtOH, $90{ }^{\circ} \mathrm{C}, 16 \mathrm{~h}$; (v) TFAA, pyridine, $0-120^{\circ} \mathrm{C}$, $16 \mathrm{~h}$; (vi) neat, $150{ }^{\circ} \mathrm{C}, 90 \mathrm{~h}$ 


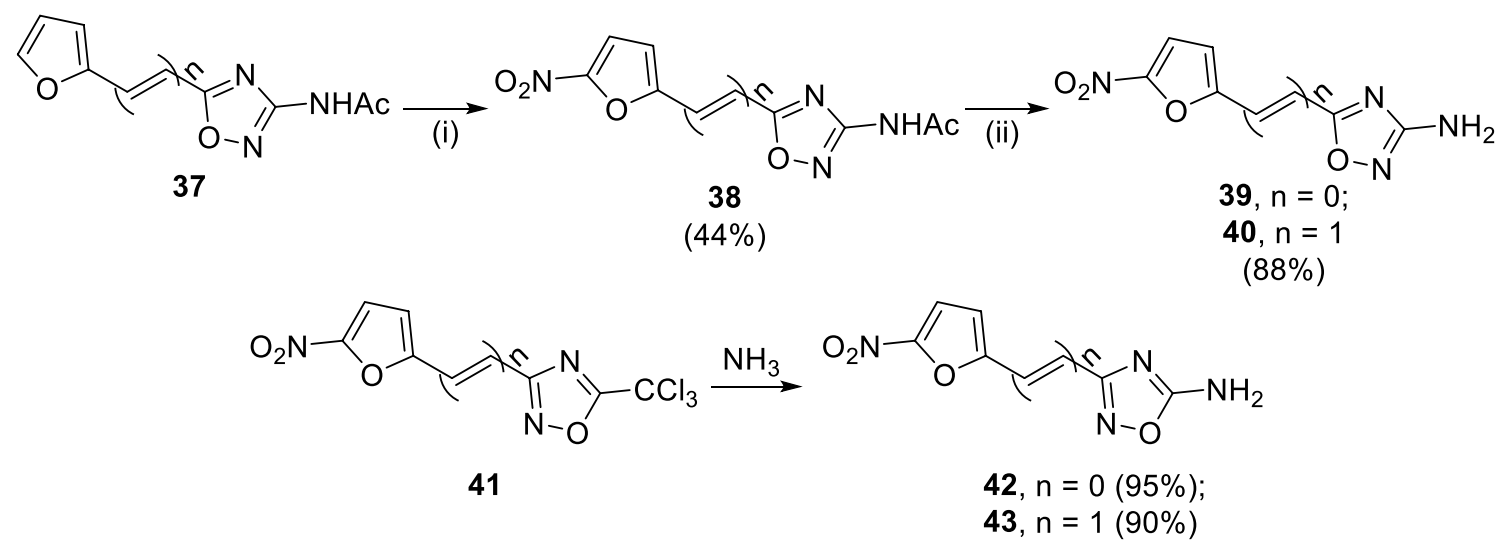

Scheme 7 Synthesis of nitrofuryl substituted 3-amino-1,2,4-oxadiazoles (39/40) and 5-amino-1,2,4-oxadiazoles (42/43) having potent antimicrobial activity. Conditions: (i) $\mathrm{HNO}_{3}, \mathrm{Ac}_{2} \mathrm{O}, 15^{\circ} \mathrm{C}, 30 \mathrm{~min}$; (ii) $10 \% \mathrm{HCl}$ (ethanolic), $3 \mathrm{~h}$

of this compound in rats resulted in low systemic clearance with moderate oral bioavailability.

In 1969, Breuer reported that 5-nitrofuryl substituted 3-amino-1,2,4-oxadiazoles and 5-amino-1,2,4-oxadiazoles with antimicrobial activity [49]. The furyl oxadiazoles (37) upon nitration with nitric acid and acetic anhydride provided 5-nitrofuryl derivatives (38, Scheme 7), which could be cleaved by warm ethanolic $\mathrm{HCl}$ to afford the target compounds (39/40), wherein compound 41 was found with broad anti-microbial spectrum. The reaction of trichloromethyl substituted 1,2,4-oxadiazoles (41) with $\mathrm{NH}_{3}$ yielded 3-substituted 5-amino 1,2,4-oxadiazoles (42/43). Upon its biological evaluation, the compound $\mathbf{4 3}$ was found to be the most potent antimicrobial compound having minimum inhibitory concentration (MIC) against various microorganism Staphylococcus aureus $(0.15 \mu \mathrm{g} / \mathrm{mL})$, Salmonella schottmulleri $(0.05 \mu \mathrm{g} / \mathrm{ml})$, Pseudomonas aeruginosa $(7.8 \mu \mathrm{g} / \mathrm{mL})$, Proteus vulgaris $(9.4 \mu \mathrm{g} / \mathrm{mL})$, Escherichia coli $(0.05 \mu \mathrm{g} /$ $\mathrm{mL})$, Candida albicans $(12.5 \mu \mathrm{g} / \mathrm{mL})$, Trichophyton mentagrophytes $(6.3 \mu \mathrm{g} / \mathrm{mL})$ and Fusarium bulbilgenum $(12.5 \mu \mathrm{g} /$ $\mathrm{mL}$ ). Against Mycobacterium tuberculosis, compound (43) was found to be most effective with MIC of $6.3 \mu \mathrm{g} / \mathrm{mL}$ among all other 1,2,4-oxadiazoles.

Mobashery et al. reported the use of 1,2,4-oxadiazole (Scheme 8 ) class of non- $\beta$-lactam antibiotics having activity towards Gram-positive bacteria along with good bioavailability [64]. Through in silico screening of 1.2 million compounds from ZINC database against penicillin-binding protein 2a (PBP2a), compound 49 has shown good MIC against $S$. aureus and E. faecium with better reproducibility. From the synthesized 370 structural derivatives of $\mathbf{4 9}$, compounds $\mathbf{5 2}$ and $\mathbf{5 3}$ were found most effective against the panel of clinical microorganism. Further, they demonstrated bactericidal activity against vancomycin and linezolid resistant MRSA along with other strains of bacterial. The synthesis of compound 49 was achieved by the reaction of 4-iodobenzonitrile (44) with 4-substituted phenol (45) in the presence of $\mathrm{Cul}$ and dicaesium carbonate at $90{ }^{\circ} \mathrm{C}$ followed by amidoxime formation using di-isopropyl ethyl amine (DIPEA) in THF and cyclocondensation to yield 1,2,4-oxadiazole using tetrabutylammonium fluoride (TBAF) in tetrahydrofuran (THF). To synthesize, intermediate 47 was reacted with 4-tert-butyl dimethyl silyl benzoyl chloride at $120{ }^{\circ} \mathrm{C}$ in toluene to yield $\mathbf{5 0}$ followed by desilylation using TBAF to yield 51. In a similar fashion, $\mathbf{5 3}$ was obtained by treatment of $\mathbf{5 2}$ with 4-nitrobenzoyl chloride in toluene under reflux followed by catalytic reduction of nitro functional group to its amino counterpart (53). Further, they have studied these compounds through in vivo mouse model and revealed $100 \%$ oral bioavailability.

In continuation of their efforts for exploration of SAR of 1,2,4-oxadiazoles [65], they reported the use of about 120 synthetic oxadiazole derivatives (52) as antibiotics acting against several microorganisms and established their structure-activity relationships (Scheme 9) [66]. The reaction of 4-fluro or 4-iodobenzonitrile (54) with 4-substituted phenol derivatives (45) via nucleophilic aromatic substitution or Ullmann coupling resulted in the formation of 4,4'-diphenyl ether (55), which upon the treatment with hydroxylamine (56) in ethanol at reflux followed by cyclization with acyl chloride (obtained by reacting substituted benzoic acids or heteroaromatic carboxylic acids with oxalyl chloride or thionyl chloride) in pyridine/ toluene/1,4-dioxane to obtain 1,2,4-oxadiazoles (58). The para position substitution $\left(\mathrm{R}^{1}\right)$ improved metabolic stability and diminished the rate of excretion. The synthesized oxadiazoles have been found active against grampositive bacteria including drug sensitive and methicillin/ vancomycin/linezolid-resistant $S$. aureus. Replacement of pyrazole with indole broadened the spectrum against gram-positive organisms. The highest activity (MIC of $4 \mu \mathrm{g} / \mathrm{mL}$ ) was observed for antibiotic 58 having indol-5-yl 


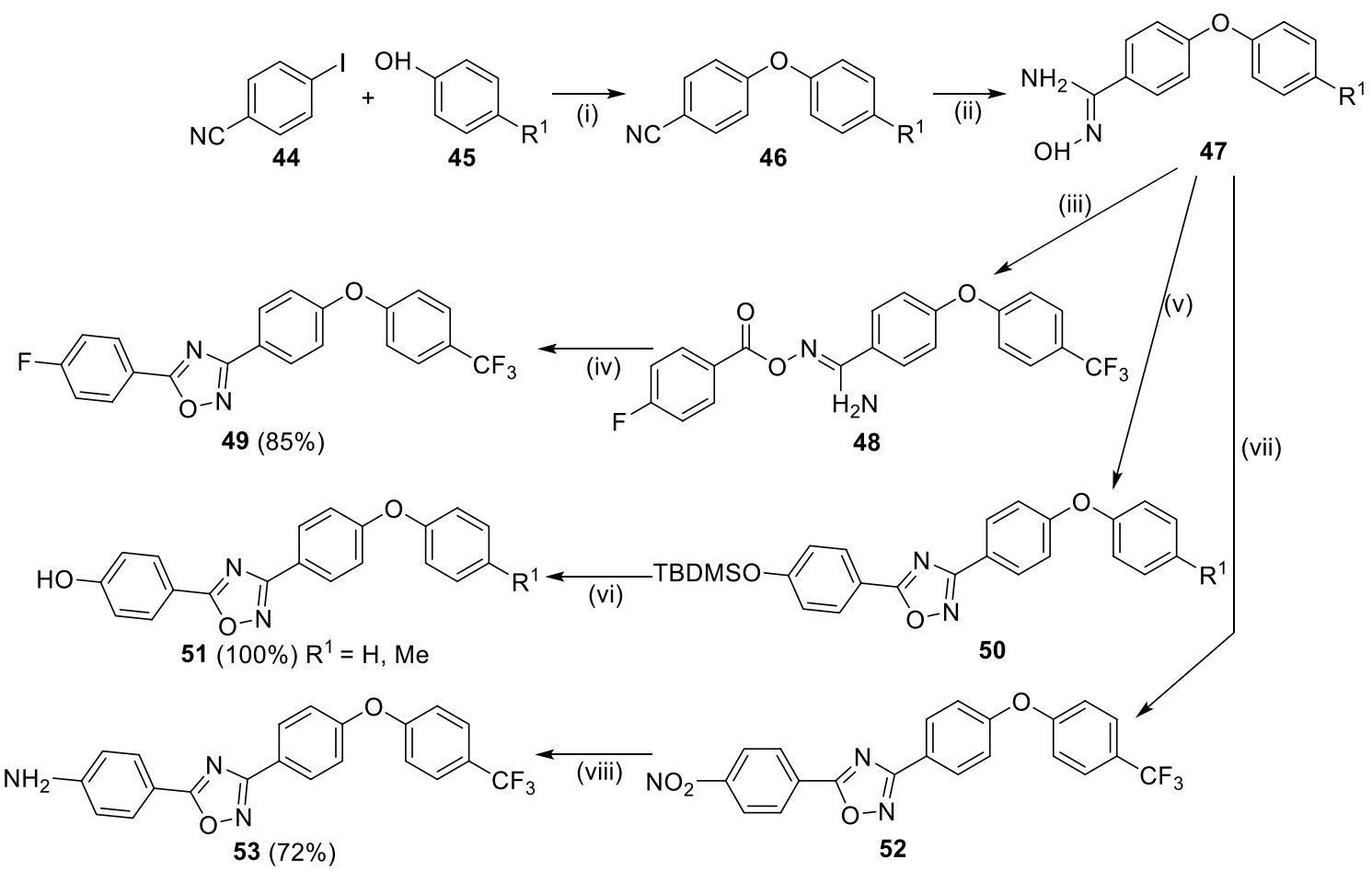

Scheme 8 Synthesis of 1,2,4-oxadiazoles (49/51/53) as non- $\beta$-lactam inhibitors. Conditions: (i) $\mathrm{Cul}, \mathrm{Cs}_{2} \mathrm{CO}_{3}, N, N$-dimethyl, glycine $\mathrm{HCl}$, 1,4-dioxane, $90{ }^{\circ} \mathrm{C}$; (ii) $\mathrm{NH}_{2} \mathrm{OH}, \mathrm{EtOH}$, reflux, $3 \mathrm{~h}$; (iii) DIPEA, DCM, $0{ }^{\circ} \mathrm{C} \longrightarrow \mathrm{rt}$; (iv) TBAF, THF, rt, $24 \mathrm{~h}$; (v) 4-TBDMS-BzCl,
$\mathrm{PhMe}, 120{ }^{\circ} \mathrm{C}$, overnight; (vi) TBAF, (1 equiv), THF, $<1 \mathrm{~min}$; (vii) 4- $\mathrm{NO}_{2}-\mathrm{BzCl}, \mathrm{PhMe}$, reflux, $5.5 \mathrm{~h}$; (viii) $\mathrm{Fe}, \mathrm{H}_{2} \mathrm{O}, \mathrm{HCl}, \mathrm{EtOH}, 95{ }^{\circ} \mathrm{C}$, $2 \mathrm{~h}$
Scheme 9 Structure activity relationship of 1,2,4-oxadiazole antibiotics 58. Conditions:

(i) $\mathrm{K}_{2} \mathrm{CO}_{3}$, DMF, $60-100{ }^{\circ} \mathrm{C}$ or $\mathrm{Cul}, \mathrm{Cs}_{2} \mathrm{CO}_{3}, \mathrm{~N}, \mathrm{~N}$ dimethylglycine' $\mathrm{HCl}$ 1,4-dioxane, $90{ }^{\circ} \mathrm{C}$; (ii) $\mathrm{NH}_{2} \mathrm{OH}, \mathrm{EtOH}$ and (iii) pyridine/toluene/1,4dioxane<smiles>[X]c1ccc(Oc2ccc(C#N)cc2)cc1</smiles><smiles>[R2]c1nc(-c2ccc(Oc3ccc([R1]C([R20])C(=O)Cl)cc3)cc2)no1</smiles>

$\left(\mathrm{R}^{2}\right)$ and 4-trifluoromethyl substitutions against $S$. aureus ATCC. The same compound was also found effective against in vivo mouse peritonitis model of infection with better pharmacokinetic and bioavailability profile. Other 4-trifluoromethyl $\left(\mathrm{R}^{1}\right)$ substituted antibiotics with 4- $N$-isopropyl amino-pyrazol-5-yl ( $\mathrm{R}^{2}$, MIC of $\left.0.5 \mu \mathrm{g} / \mathrm{mL}\right)$ and 4-ethynyl-pyrazol-5-yl ( $\mathrm{R}^{2}$, MIC of $0.25 \mu \mathrm{g} / \mathrm{mL}$ ) showed good anti-bacterial activity with the highest toxicity towards mammalian cells. However, these potent antibiotics were found ineffective against other microbial strains.
Aguiar and colleagues evaluated the antimicrobial properties of 3,5-diphenyl or 3-pyridino-5-phenyl 1,2,4-oxadiazoles (62) [58]. These derivatives were synthesized (Scheme 10) by cyclization of amidoxime derivatives (60), synthesized from hydroxylamine hydrochloride and anhydrous sodium carbonate with acyl chloride (61, obtained from corresponding substituted carboxylic acid and thionyl chloride). Upon the biological evaluation of all the synthesized compounds against E. coli, P. aeruginosa, S. aureus, P. mirabilis, E. faecalis, the compounds $62 \mathbf{a}\left(\mathrm{R}^{1}=4-\mathrm{Cl}\right.$, 
Scheme 10 Synthesis of 1,2,4-oxadiazole derivatives (62) having anti-microbial property. Conditions: (i) EtOH, $\mathrm{H}_{2} \mathrm{O}$, reflux, $5 \mathrm{~h}$ and (ii) $\mathrm{PhMe}$, reflux, $5 \mathrm{~h}$

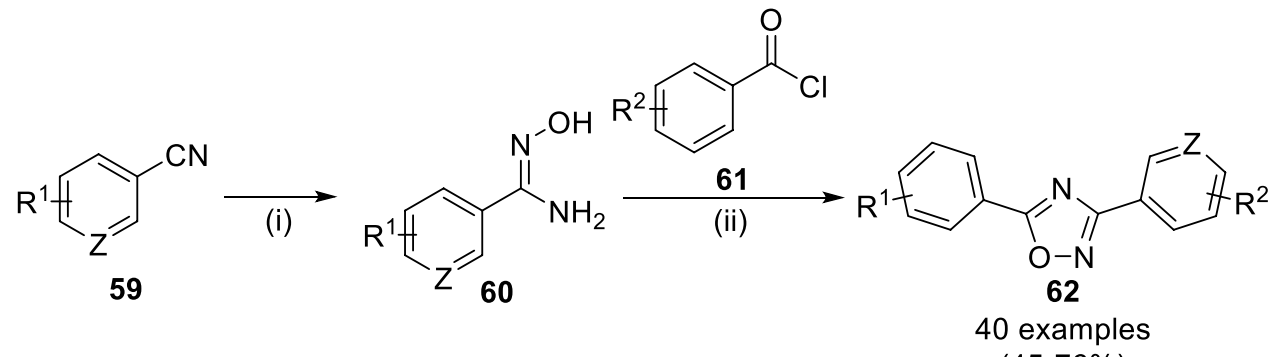

$(45-76 \%)$

$\mathrm{R}^{1}=\mathrm{H}, 2-\mathrm{Cl}, 3-\mathrm{Cl} ; \mathrm{R}^{2}=2-\mathrm{OH}, \mathrm{H}, 2-\mathrm{Cl}, 2-\mathrm{Br}, 3-\mathrm{Br}, 2-\mathrm{I}, 2-$

$\mathrm{NO}_{2}, 3-\mathrm{NO}_{2}, 4-\mathrm{NO}_{2}, 3,5-\left(\mathrm{NO}_{2}\right), 2-\mathrm{Cl}-5-\mathrm{NO}_{2} ; \mathrm{Z}=\mathrm{CH}, \mathrm{N}$

$\left.\mathrm{R}^{2}=2-\mathrm{NO}_{2}, \mathrm{Z}=\mathrm{C}\right), \mathbf{6 2} \mathbf{b}\left(\mathrm{R}^{1}=4-\mathrm{Cl}, \mathrm{R}^{2}=4-\mathrm{NO}_{2}, \mathrm{Z}=\mathrm{C}\right)$ and 62c $\left(\mathrm{R}^{1}=4-\mathrm{Cl}, \mathrm{R}^{2}=2-\mathrm{Cl}-5-\mathrm{NO}_{2}, \mathrm{Z}=\mathrm{C}\right)$ have been found with the best anti-bacterial activity. The compounds with nitro as electron-donating group have shown potent anti-bacterial activity. Further, they anticipated the mode of action of these active hits through inhibition of promising enzyme of citric acid cycle through free radical formation involving reduction of nitro to amino counterparts via enzymatic bioreduction approach.

$\mathrm{Du}$ et al. [47] synthesized 3',4'-diaryl-4' $H$ -

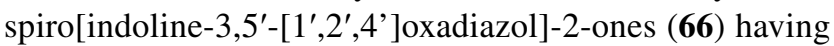
antibacterial activity (Scheme 11) by the reaction of isatin (63) and aniline (64) in ethanol at $\mathrm{rt}$ followed by 1,3-dipolar cycloaddition of the intermediates with $N$-hydroxybenzimidoyl chloride $(\mathbf{6 5})$ in the presence of catalytic amount of DMAP (10 mol\%) at $\mathrm{rt}$ for $3 \mathrm{~h}$. Compound $\mathbf{6 6}\left(\mathrm{R}^{1}=\mathrm{H}\right.$; $\mathrm{R}^{2}=\mathrm{Me} ; \mathrm{R}^{3}=\mathrm{NO}_{2}$ ) was found to be most effective against S. epidermidis, wherein the anti-bacterial activity could be attributed to the electron-withdrawing group on phenyl ring. However, none of the compounds were found more effective than the anti-bacterial drug, levofloxacin against Staphylococcus epidermidis, Escherichia coli, Staphylococcus aureus and Klebsiella pneumoniae.

The synthetic strategy of 1,2,4-oxadiazole hybrids as anti-bacterial agents acting against both gram-positive and gram-negative bacteria has been presented in Scheme 12 reported by Baykov et al. [46] The substituted 2-imidazoline (67) on reaction with hydroxylamine hydrochloride (4) in alkaline ethanolic medium at $80{ }^{\circ} \mathrm{C}$ formed $\mathrm{N}$-aryl amidoxime (68), which was reacted with methyl carboxylate (69) in DMSO added with powdered caustic soda to yield 70. In the reverse way, treatment of $N$-aryl methyl ester (71) and $N$-alkyl amidoxime (68) yielded 1,2,4-oxadiazoles. Compound $\mathbf{7 0}$ being $p$-phenylene derivative with $\mathrm{R}^{1}=\mathrm{Me}, \mathrm{R}^{2}=3,4-(\mathrm{Cl})_{2}-\mathrm{C}_{6} \mathrm{H}_{3}$ resulted in most potent compound having MIC in $8-16 \mu \mathrm{g} / \mathrm{mL}$ where bacteriostatic property has been also observed with $p$-phenylene derivative 73 in $8-32 \mu \mathrm{g} / \mathrm{mL}\left(\mathrm{R}^{1}=\mathrm{H}, \mathrm{R}^{2}=3-\mathrm{Cl}-\mathrm{C}_{6} \mathrm{H}_{4}\right.$ and $\mathrm{R}^{1}=\mathrm{Me}$, $\mathrm{R}^{2}=4-\mathrm{Me}-\mathrm{C}_{6} \mathrm{H}_{4}$ ).

In 2017, Raval and co-workers have synthesized novel 2-morpholinoquinoline nucleus appended 1,2,4-oxadiazoles having antimicrobial and antifungal activity (Scheme 13) [59]. The treatment of 2-chloroquinoline3 -carbaldehydes (74) in THF (30\%) with aqueous ammonia (75) and sublimed iodine at $\mathrm{rt}$ for $30 \mathrm{~min}$ yielded 2-chloro-6-substituted quinoline-3-carbonitrile (76). The next reaction of $\mathbf{7 6}$ with morpholine (77) in presence of $\mathrm{K}_{2} \mathrm{CO}_{3}$ in DMF followed by reaction with hydroxylamine hydrochloride in alkaline mixture of ethanol:water (7:3) to synthesize amidoximes (79). Finally, the condensation

Scheme 11 Synthesis of $3^{\prime}, 4^{\prime}$-diaryl-4' $H$ spiro[indoline- $3,5^{\prime}-\left[1^{\prime}, 2^{\prime}, 4^{\prime}\right]$ oxadiazol]-2-ones (66) via DMAP-catalyzed domino reaction. Conditions: (i) $\mathrm{EtOH}, \mathrm{rt}, 3 \mathrm{~h}$, DMAP (10 mol\%), rt, $3 \mathrm{~h}$<smiles>[R]c1ccc(C2=NOC3(C(=O)Nc4ccc([R16])cc43)N2c2ccc([R])cc2)cc1</smiles>

22 examples

(78-95\%)

$\mathrm{R}^{1}=\mathrm{H}$, Me, Et, iPr, OMe, F, Cl, Br, I; $\mathrm{R}^{2}=\mathrm{H}, \mathrm{Me}, \mathrm{Pr}, \mathrm{F}, \mathrm{Cl}$, $\mathrm{Br}, \mathrm{I} ; \mathrm{R}^{3}=\mathrm{H}, \mathrm{Me}, \mathrm{OMe}, \mathrm{OEt}, \mathrm{F}, \mathrm{Cl}, \mathrm{Br}, \mathrm{NO}_{2}, \mathrm{NMe}_{2}, \mathrm{CN}, \mathrm{OBn}$ 


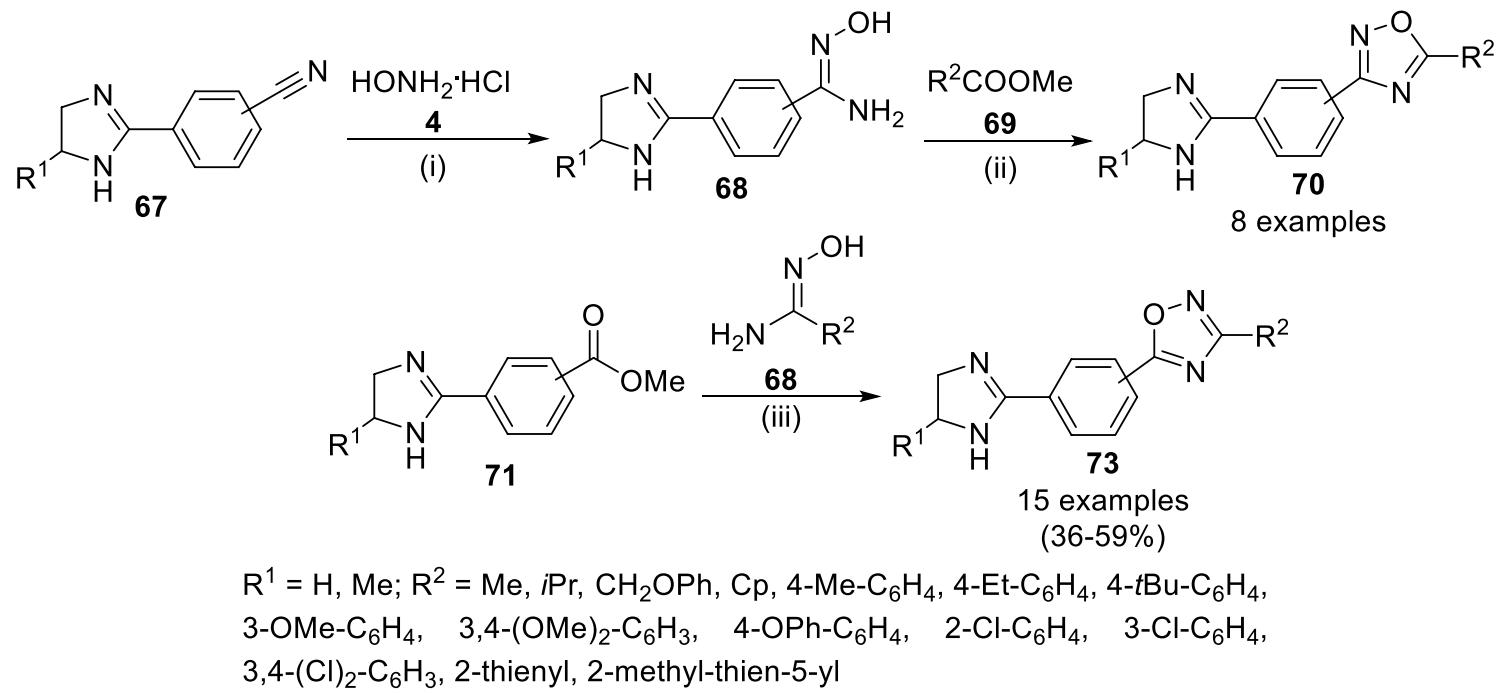

Scheme 12 Synthesis of 1,2,4-oxadiazoles (73) from $\mathrm{N}$-aryl amidoxime (72) and alkyl ester (71). Conditions: (i) $\mathrm{NaHCO}_{3}, \mathrm{EtOH}, 80{ }^{\circ} \mathrm{C}, 6 \mathrm{~h}$, (ii) $\mathrm{NaOH}, \mathrm{DMSO}, \mathrm{rt}$; (iii) $\mathrm{NaOH}, \mathrm{DMSO}, \mathrm{rt}, 4 \mathrm{~h}$

Scheme 13 Synthesis of 2-morpholinoquinoline integrated 1,2,4-oxadiazole scaffolds (81). Conditions: (i) $\mathrm{I}_{2}$, THF, reflux, $2 \mathrm{~h}$; (iii) $\mathrm{NH}_{2} \mathrm{OH} \cdot \mathrm{HCl}$ $\mathrm{Na}_{2} \mathrm{CO}_{3}, \mathrm{EtOH}$, reflux, $5 \mathrm{~h}$ and (iv) $\mathrm{EDC} \cdot \mathrm{HCl}, \mathrm{DCM}, \mathrm{rt}, 30 \mathrm{~min}$ then reflux, $2 \mathrm{~h}$; (v) $\mathrm{NaOAc}$, EtOH, reflux, $3 \mathrm{~h}$ rt, $30 \mathrm{~min}$; (ii) DMF, $\mathrm{K}_{2} \mathrm{CO}_{3}$,

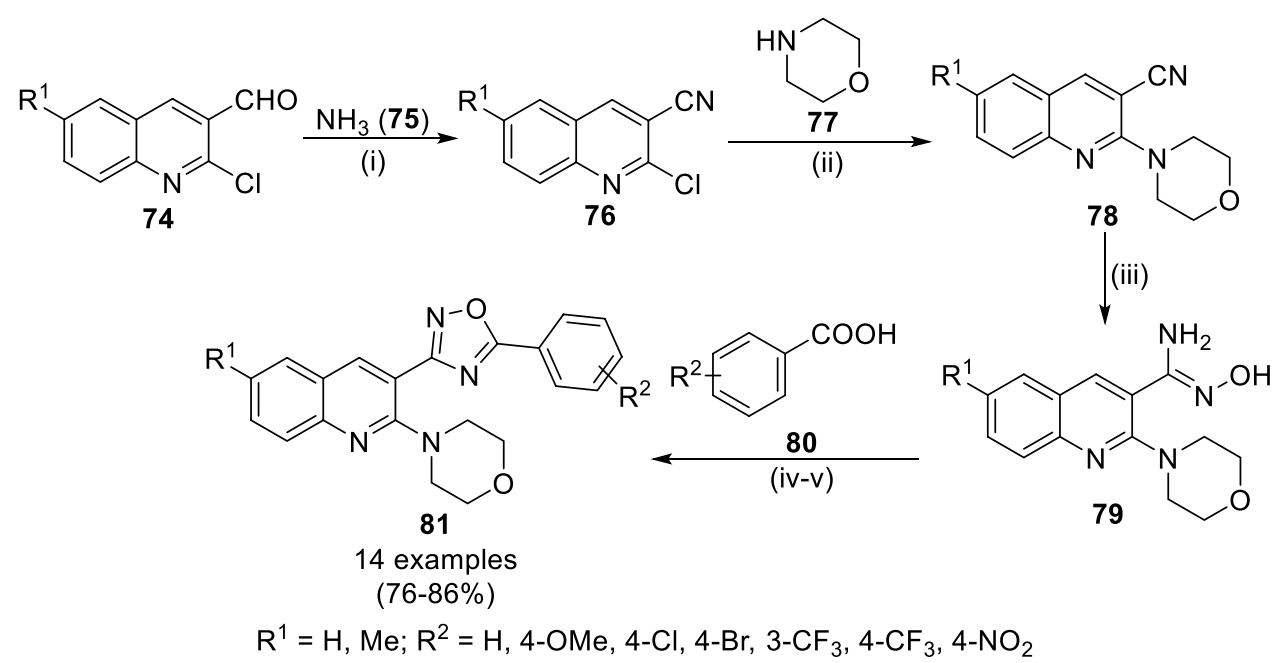

of aromatic acids $(\mathbf{8 0})$ in dichloromethane using coupling reagent ethyl-( $N, N^{\prime}$-dimethylamino)propylcarbodiimide hydrochloride $(\mathrm{EDC} \cdot \mathrm{HCl})$ under nitrogen atmosphere to obtain the target compounds, 1,2,4-oxadiazoles (81). All the target compounds were evaluated for assessment of drug likeness using Lipinski's rule of five indicating their druggability. The evaluation of anti-microbial potential of final compounds revealed compounds 81a-d $\left(\mathrm{R}^{1}=\mathrm{Me}\right.$ and $\mathrm{R}^{2}=4-\mathrm{NO}_{2}, 4-\mathrm{Cl}, 4-\mathrm{CF}_{3}, 3-\mathrm{CF}_{3}$, respectively) as most potent compounds against gram-positive and gram-negative microbial and compounds fungal strains having better potency than ampicillin and griseofulvin. The presence of electron-withdrawing groups such nitro and trifluoromethyl on 5-phenyl ring have increased the anti-infective potential of the 1,2,4-oxadiazoles.
Recently, Tan et al. reported the synthesis of benzamide coupled pyridine anchored 1,2,4-oxadiazoles (89) as anti-fungal agents (Scheme 14) [67]. The esterification of 2-chloro-5-iodobenzoic acid (81) was achieved in methanol at reflux followed by cyanation using copper cyanide in the presence of L-proline and treatment with hydroxyl amine hydrochloride (4) yielded benzamidoxime (84). Compound 84 was further reacted with 3,6-dichloropicolinoyl chloride (85) to 2-chloro-5-(5-(3,6-dichloropyridin-2-yl)-1,2,4oxadiazol-3-yl)benzoate (86) via cyclization followed by alkali catalyzed hydrolysis to yield carboxylic acid (87). The amidation reaction of $\mathbf{8 6}$ with substituted aniline (88) at $0{ }^{\circ} \mathrm{C}$ for $7 \mathrm{~h}$ yielded $(\mathbf{8 9})$. All the synthetic targets were evaluated through in vitro mycelia growth inhibition method against fungal strains including Alternaria solani, FusaHum 
Scheme 14 Synthetic scheme for 3,5-disusbtituted 1,2,4-oxadiazoles (89) as anti-fungal agents. Conditions: (i) $\mathrm{MeOH}$, reflux, $8 \mathrm{~h}$; (ii) $\mathrm{CuCN}$, L-proline, DMF, 11 h; (iii) EtOH, rt; (iv) $\mathrm{PhMe}$; (v) $\mathrm{NaOH}$, THF, $2 \mathrm{~h}$; (vi) $0{ }^{\circ} \mathrm{C}, 8 \mathrm{~h}$<smiles>O=C(O)c1cc(I)ccc1Cl</smiles>

81
82<smiles>[R6]c1ccc(I)cc1C(=O)OC</smiles>

(ii)<smiles>COC(=O)c1cc(C#N)ccc1Cl</smiles><smiles>COC(=O)c1cc(-c2noc(-c3nc(Cl)ccc3Cl)n2)ccc1Cl</smiles>
$\mathrm{HO}_{-\mathrm{N}}$<smiles>COC(=O)c1cc(/C(N)=N/O)ccc1Cl</smiles>

84<smiles>[R][R]c1ccc(NC(=O)c2cc(-c3noc(-c4ncc(Cl)cc4Cl)n3)ccc2Cl)cc1</smiles>

$\mathrm{R}^{1}=\mathrm{H}, 2-\mathrm{Me}$, 3-Me, 4-Me, 4-tBu, 2,4-(Me) 2 , 2-F, 3-F, 4-F, 2-Cl, 3-Cl, 4-Cl, 4-Br, 3-CF 3

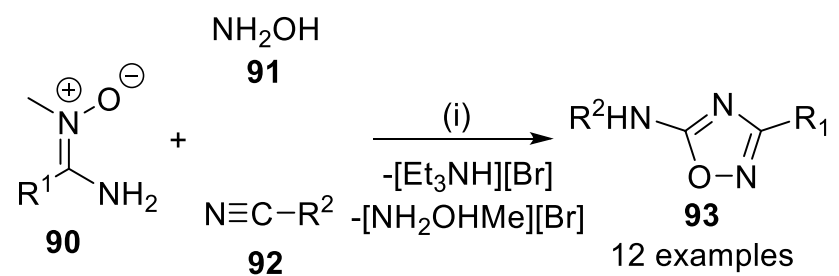

$(29-85 \%)$

$\mathrm{R}^{1}=\mathrm{Me}, \mathrm{C}_{6} \mathrm{H}_{5}, 4-\mathrm{NMe}_{2}-\mathrm{C}_{6} \mathrm{H}_{4}, 2-\mathrm{Cl}-\mathrm{C}_{6} \mathrm{H}_{4}, 4-\mathrm{Cl}-\mathrm{C}_{6} \mathrm{H}_{4}$, 3- $\mathrm{CF}_{3}-\mathrm{C}_{6} \mathrm{H}_{4}$, 2-pyridyl, 3-pyridyl, 2-pyrimidinyl, $\mathrm{R}^{2}=$ $t \mathrm{Bu}, \mathrm{Cy}, 4-\mathrm{OMe}-\mathrm{C}_{6} \mathrm{H}_{4}, 2,6-(\mathrm{Me})_{2}-\mathrm{C}_{6} \mathrm{H}_{3}$

Scheme 15 Synthesis of 1,2,4-oxadiazoles (93) active as anti-bacterial agents. Conditions: (i) $\mathrm{Br}_{2}, \mathrm{Et}_{3} \mathrm{~N}, \mathrm{CHCl}_{3}, \mathrm{MeOH}$, rt, 10 min

graminearum, Cercospora arachidicola, Phytophthora capsica, Sclerotinia sclerotiorum, Botrytis cinereal, Thanatephorus cucumeris and Fusarium oxysporum and these results were compared with fluxapyroxad, a broad-spectrum fungicide. Compounds $87\left(\mathrm{R}^{1}=2-\mathrm{F}\right)$ showed the good inhibitory activity (90.5\%) against Botrytis cinereal, respectively.

Kukushkin and coworkers reported 5-amino-1,2,4-oxadiazoles (93) with higher anti-bacterial activity against multidrug-resistant strains such as Staphylococcus aureus and Klebsiella pneumonia (Scheme 15) [60]. These were prepared from different synthetic strategies involving the use of aminonitrone (90), hydroxylamine (91) and isocyanide (92) at $\mathrm{rt}$ in $29-86 \%$ yields. However, none of the compounds were found superior in activity as compared to ciprofloxacin, the currently marketed anti-bacterial drug.

\section{Summary and future directions}

In a nutshell, the synthesis of 1,2,4-oxadiazoles has been recognized as the key pharmacophore for broad-spectrum anti-infective or anti-microbial activities including antifungal, anti-bacterial, anti-trypanosomal, anti-malarial, anti-tubercular and anti-viral activities. In general, these scaffolds can be synthesized from amidoxime (obtained from reaction of nitrile and hydroxylamine) with carbonyl derivatives such as acyl chloride, ester, carboxylic acid or isatin. Mechanistically, the reaction of amidoxime with aldehyde yields the 1,2,4-oxadiazoline, which can be oxidized to 1,2,4-oxadiazole with the stoichiometric assistance of oxidizing agents. The objective behind the present work has been set to create the spotlight around 1,2,4-oxadiazole considering their synthetic strategies and usefulness as anti-parasitic activity for the benefit of medicinal chemists to design new scaffolds with potential activity of interest.

Authors Contribution SJC Literature review, Writing-Original draft and revised manuscript preparation, Reviewing and Editing; TMP Writing-Original draft preparation; BPD Writing-Original draft preparation; TMD Conceptualization, Supervision, Writing- Original draft and revised manuscript preparation, Reviewing and Editing.

\section{Declarations}

Conflict of interest The authors declare no competing financial interest. 


\section{References}

1. Jadhavar PS, Vaja MD, Dhameliya TM, Chakraborti AK (2015) Oxazolidinones as anti-tubercular agents: Discovery, development and future perspectives. Curr Med Chem 22:4379-4397

2. Global Tuberculosis Report 2021. https://www.who.int/teams/ global-tuberculosis-programme/tb-reports/global-tuberculosisreport-2021. Accessed 27 Oct 2021

3. Malaria. https://www.who.int/news-room/fact-sheets/detail/malar ia. Accessed 15 Oct 2021

4. Barrett MP, Burchmore RJS, Stich A et al (2003) The trypanosomiases. Lancet 362:1469-1480

5. Ryu S, Song PI, Seo CH et al (2014) Colonization and infection of the skin by $S$. aureus: immune system evasion and the response to cationic antimicrobial peptides. Int J Mol Sci 15:8753-8772

6. Ashour HM, Elkhatib WF, Rahman MM, Elshabrawy HA (2020) Insights into the recent 2019 novel coronavirus (SARS-CoV-2) in light of past human coronavirus outbreaks. Pathogens 9:e186

7. Gajjar ND, Dhameliya TM, Shah GB (2021) In search of RdRp and Mpro inhibitors against SARS CoV-2: molecular docking, molecular dynamic simulations and ADMET analysis. J Mol Struct 1239:130488

8. Nagar PR, Gajjar ND, Dhameliya TM (2021) In search of SARS CoV-2 replication inhibitors: virtual screening, molecular dynamics simulations and ADMET analysis. J Mol Struct 1246:131190

9. Nikaido H (2009) Multidrug resistance in bacteria. Annu Rev Biochem 78:119-146

10. Verma T, Aggarwal A, Singh S et al (2022) Current challenges and advancements towards discovery and resistance of antibiotics. J Mol Struct 1248:131380

11. Dhameliya TM, Chourasiya SS, Mishra E et al (2017) Rationalization of benzazole-2-carboxylate versus benzazine-3-one/ benzazine-2,3-dione selectivity switch during cyclocondensation of 2-aminothiophenols/phenols/anilines with 1,2-biselectrophiles in aqueous medium. J Org Chem 82:10077-10091

12. Bhakhar KA, Sureja DK, Dhameliya TM (2022) Synthetic account of indoles in search of potential anti-mycobacterial agents: a review and future insights. J Mol Struct 1248:131522

13. Dhameliya TM, Donga HA, Vaghela PV et al (2020) A decennary update on applications of metal nanoparticles (MNPs) in the synthesis of nitrogen- and oxygen-containing heterocyclic scaffolds. RSC Adv 10:32740-32820

14. Othman AA, Kihel M, Amara S (2019) 1,3,4-Oxadiazole, 1,3,4-thiadiazole and 1,2,4-triazole derivatives as potential antibacterial agents. Arab J Chem 12:1660-1675

15. Dhameliya TM, Bhakhar KA, Gajjar ND et al (2022) Recent advancements and developments in search of anti-tuberculosis agents: a quinquennial update and future directions. J Mol Struct 1248:131473

16. Kerru N, Gummidi L, Maddila S et al (2020) A review on recent advances in nitrogen-containing molecules and their biological applications. Molecules 25:1909

17. Jadhavar PS, Patel KI, Dhameliya TM et al (2020) Benzimidazoquinazolines as new potent anti-TB chemotypes: design, synthesis, and biological evaluation. Bioorg Chem 99:103774

18. Dhameliya TM, Patel KI, Tiwari R et al (2021) Design, synthesis, and biological evaluation of benzo[d]imidazole-2-carboxamides as new anti-TB agents. Bioorg Chem 107:104538

19. Boström J, Hogner A, Llinàs A et al (2012) Oxadiazoles in medicinal chemistry. J Med Chem 55:1817-1830

20. Nobeli I, Price SL, Lommerse JPM, Taylor R (1997) Hydrogen bonding properties of oxygen and nitrogen acceptors in aromatic heterocycles. J Comput Chem 18:2060-2074

21. Patani GA, LaVoie EJ (1996) Bioisosterism: a rational approach in drug design. Chem Rev 96:3147-3176
22. Salahuddin MA, Yar MS et al (2017) Updates on synthesis and biological activities of 1,3,4-oxadiazole: a review. Synth Commun 47:1805-1847

23. Banik BK, Sahoo BM, Kumar BVVR et al (2021) Green synthetic approach: an efficient eco-friendly tool for synthesis of biologically active oxadiazole derivatives. Molecules 26:1163

24. Scopus. https://www.scopus.com/. Accessed 27 Sep 2021

25. Biernacki K, Daśko M, Ciupak O et al (2020) Novel 1,2,4-oxadiazole derivatives in drug discovery. Pharmaceuticals 13:111

26. Pevear DC, Tull TM, Seipel ME, Groarke JM (1999) Activity of pleconaril against enteroviruses. Antimicrob Agents Chemother 43:2109-2115

27. Tadikonda R, Nakka M, Gajula MB et al (2014) Efficient and convenient protocol for the synthesis of 3,5-disubstituted 1,2,4-oxadiazoles using $\mathrm{HClO} 4-\mathrm{SiO}_{2}$ as a heterogeneous recyclable catalyst. Synth Commun 44:1978-1986

28. Coupar IM, Hedges A, Metcalfe HL, Turner P (1969) Effect of aminophylline, butalamine and imolamine on human isolated smooth muscle. J Pharm Pharmacol 21:474-475

29. Ryan NJ (2014) Ataluren: First global approval. Drugs 74:1709-1714

30. Gaetani E, Laureri C, Vitto M (1995) GC-ITD detection and quantitative analysis of Proxazole in cows' plasma and milk. J Pharm Biomed Anal 13:335-337

31. Carbone M, Li Y, Irace C et al (2011) Structure and cytotoxicity of phidianidines A and B: first finding of 1,2,4-oxadiazole system in a marine natural product. Org Lett 13:2516-2519

32. Bora OR, Dar B, Pradhan V, Farooqui M (2014) [1,2,4]-Oxadiazoles: synthesis and biological applications. Mini Rev Med Chem 14:355-369

33. Shamsi F, Hasan P, Queen A et al (2020) Synthesis and SAR studies of novel 1,2,4-oxadiazole-sulfonamide based compounds as potential anticancer agents for colorectal cancer therapy. Bioorg Chem 98:103754

34. Loboda KB, Valjavec K, Štampar M et al (2020) Design and synthesis of 3,5-substituted 1,2,4-oxadiazoles as catalytic inhibitors of human DNA topoisomerase II $\alpha$. Bioorg Chem 99:103828

35. Abdelhameid MK, Mohammed MR (2019) Design, synthesis, and cytotoxicity screening of 5-aryl-3-(2-(pyrrolyl) thiophenyl)-1,2,4oxadiazoles as potential antitumor molecules on breast cancer MCF-7 cells. Bioorg Chem 86:609-623

36. Caneschi W, Enes KB, Carvalho de Mendonça C et al (2019) Synthesis and anticancer evaluation of new lipophilic 1,2,4 and 1,3,4-oxadiazoles. Eur J Med Chem 165:18-30

37. Moniot S, Forgione M, Lucidi A et al (2017) Development of 1,2,4-oxadiazoles as potent and selective inhibitors of the human deacetylase sirtuin 2: structure-activity relationship, X-ray crystal structure, and anticancer activity. J Med Chem 60:2344-2360

38. Mohamed MFA, Marzouk AA, Nafady A et al (2020) Design, synthesis and molecular modeling of novel aryl carboximidamides and 3-aryl-1,2,4-oxadiazoles derived from indomethacin as potent anti-inflammatory iNOS/PGE2 inhibitors. Bioorg Chem 105:104439

39. Youssif BGM, Mohamed MFA, Al-Sanea MM et al (2019) Novel aryl carboximidamide and 3-aryl-1,2,4-oxadiazole analogues of naproxen as dual selective COX-2/15-LOX inhibitors: design, synthesis and docking studies. Bioorg Chem 85:577-584

40. Yatam S, Gundla R, Jadav SS et al (2018) Focused library design and synthesis of 2-mercapto benzothiazole linked 1,2,4-oxadiazoles as COX-2/5-LOX inhibitors. J Mol Struct 1159:193-204

41. Chawla G (2018) 1,2,4-Oxadiazole as a privileged scaffold for anti-inflammatory and analgesic activities: a review. Mini Rev Med Chem 18:1536-1547

42. Wang M, Liu T, Chen S et al (2021) Design and synthesis of 3-(4-pyridyl)-5-(4-sulfamido-phenyl)-1,2,4-oxadiazole derivatives as novel GSK-3 $\beta$ inhibitors and evaluation of their 
potential as multifunctional anti-Alzheimer agents. Eur J Med Chem 209:112874

43. Shetnev A, Osipyan A, Baykov S et al (2019) Novel monoamine oxidase inhibitors based on the privileged 2-imidazoline molecular framework. Bioorg Med Chem Lett 29:40-46

44. Brahmi J, Ghannay S, Bakari S et al (2016) Unprecedented stereoselective synthesis of 3-methylisoxazolidine-5-aryl-1,2,4-oxadiazoles via 1,3-dipolar cycloaddition and study of their in vitro antioxidant activity. Synth Commun 46:2037-2044

45. Ningaiah S, Bhadraiah UK, Keshavamurthy S, Javarasetty C (2013) Novel pyrazoline amidoxime and their 1,2,4-oxadiazole analogues: synthesis and pharmacological screening. Bioorg Med Chem Lett 23:4532-4539

46. Shetnev A, Baykov S, Kalinin S et al (2019) 1,2,4-oxadiazole/2imidazoline hybrids: multi-target-directed compounds for the treatment of infectious diseases and cancer. Int J Mol Sci 20:1699

47. Shi G, He X, Shang Y et al (2016) Synthesis of 3',4'-Diaryl$4^{\prime} \mathrm{H}$-spiro[indoline-3, $5^{\prime}$ - $\left[1^{\prime}, 2^{\prime}, 4^{\prime}\right]$ oxadiazol]-2-ones via DMAPcatalyzed domino reactions and their antibacterial activity. Chin J Chem 34:901-909

48. Atmaram Upare A, Gadekar PK, Sivaramakrishnan H et al (2019) Design, synthesis and biological evaluation of (E)-5-styryl-1,2,4oxadiazoles as anti-tubercular agents. Bioorg Chem 86:507-512

49. Breuer H (1969) Nitroheterocycles. I. Nitrofuryl-substituted 3-amino-1,2,4-oxadiazoles and 5-Amino-1,2,4-oxadiazoles. J Med Chem 12:708-709

50. Kim J, Jung YK, Kim C et al (2017) A novel series of highly potent small molecule inhibitors of rhinovirus replication. J Med Chem 60:5472-5492

51. dos Santos Filho JM, Leite ACL, de Oliveira BG et al (2009) Design, synthesis and cruzain docking of 3-(4-substitutedaryl)-1,2,4-oxadiazole- $N$-acylhydrazones as anti-Trypanosoma cruzi agents. Bioorg Med Chem 17:6682-6691

52. dos Santos Filho JM, de Queiroz e Silva DMA, Macedo TS et al (2016) Conjugation of $N$-acylhydrazone and 1,2,4-oxadiazole leads to the identification of active antimalarial agents. Bioorg Med Chem 24:5693-5701

53. Srivastava RM, De Almeida LA, Viana OS et al (2003) Antiinflammatory property of 3-aryl-5-(n-propyl)-1,2,4-oxadiazoles and antimicrobial property of 3-aryl-5-(n-propyl)-4,5-dihydro-1,2,4oxadiazoles: Their syntheses and spectroscopic studies. Bioorg Med Chem 11:1821-1827

54. Dos Santos Filho JM, Moreira DRM, De Simone CA et al (2012) Optimization of anti-Trypanosoma cruzi oxadiazoles leads to identification of compounds with efficacy in infected mice. Bioorg Med Chem 20:6423-6433

55. Kim J, Shin JS, Ahn S et al (2018) 3-Aryl-1,2,4-oxadiazole derivatives active against human rhinovirus. ACS Med Chem Lett 9:667-672
56. Pitasse-santos P, Sueth-santiago V, Lima MEF (2018) 1,2,4- and 1,3,4-Oxadiazoles as Scaffolds in the development of antiparasitic agents. J Braz Chem Soc 29:435-456

57. Facchinetti V, Gomes CRB, de Souza MVN (2021) Application of nitriles on the synthesis of 1,3-oxazoles, 2-oxazolines, and oxadiazoles: An update from 2014 to 2021. Tetrahedron 102:132544

58. Cunha FS, Nogueira JMR, De Aguiar AP (2018) Synthesis and antibacterial evaluation of 3,5-diaryl-1,2,4-oxadiazole derivatives. J Braz Chem Soc 29:2405-2416

59. Karad SC, Purohit VB, Thummar RP et al (2017) Synthesis and biological screening of novel 2-morpholinoquinoline nucleus clubbed with 1,2,4-oxadiazole motifs. Eur J Med Chem 126:894-909

60. Il'In MV, Sysoeva AA, Bolotin DS et al (2019) Aminonitrones as highly reactive bifunctional synthons. An expedient one-pot route to 5-amino-1,2,4-triazoles and 5-amino-1,2,4-oxadiazolespotential antimicrobials targeting multi-drug resistant bacteria. New J Chem 43:17358-17366

61. Jadhavar PS, Dhameliya TM, Vaja MD et al (2016) Synthesis, biological evaluation and structure-activity relationship of 2-styrylquinazolones as anti-tubercular agents. Bioorg Med Chem Lett 26:2663-2669

62. Pancholia S, Dhameliya TM, Shah P et al (2016) Benzo[d]thiazol2-yl(piperazin-1-yl)methanones as new anti-mycobacterial chemotypes: Design, synthesis, biological evaluation and 3D-QSAR studies. Eur J Med Chem 116:187-199

63. Dhameliya TM, Tiwari R, Banerjee A et al (2018) Benzo[d]thiazole-2-carbanilides as new anti-TB chemotypes: design, synthesis, biological evaluation, and structure-activity relationship. Eur J Med Chem 155:364-380

64. O'Daniel PI, Peng Z, Pi H et al (2014) Discovery of a new class of non- $\beta$-lactam inhibitors of penicillin-binding proteins with grampositive antibacterial activity. J Am Chem Soc 136:3664-3672

65. Ding D, Boudreau MA, Leemans E et al (2015) Exploration of the structure-activity relationship of 1,2,4-oxadiazole antibiotics. Bioorg Med Chem Lett 25:4854-4857

66. Spink E, Ding D, Peng Z et al (2015) Structure-activity relationship for the oxadiazole class of antibiotics. J Med Chem 58:1380-1389

67. Yang S, Tian XY, Ma TY et al (2020) Synthesis and biological activity of benzamides substituted with pyridine-linked 1,2,4-oxadiazole. Molecules 25:3500

Publisher's Note Springer Nature remains neutral with regard to jurisdictional claims in published maps and institutional affiliations.

\section{Authors and Affiliations}

\section{Tejas M. Dhameliya ${ }^{1} \mathbb{D}$. Shrddhaba J. Chudasma ${ }^{1} \cdot$ Tanvi M. Patel $^{1} \cdot$ Bhavarth P. Dave $^{1}$}

Tejas M. Dhameliya

tejas.dhameliya@lmcp.ac.in; tmdhameliya@gmail.com
1 L. M. College of Pharmacy, Navrangpura, Ahmedabad, Gujarat 380 009, India 